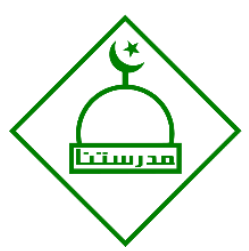

\title{
Pengaruh penggunaan media kit terhadap prestasi belajar peserta didik
}

\author{
(Penelitian di SDN Tirtalaya Kec. Pagerageung Kab. Tasikmalaya)
}

\author{
Annisa Nurul Azizah ${ }^{1}$, Nana Suryana ${ }^{2}$, Jonari Hanafi ${ }^{3}$ \\ IAI Latifah Mubarokiyah Tasikmalaya Indonesia \\ annisaazizah1996@gmail.com¹,suryanaaljoe@gmail.com²,jonarihanafi90@gmail.com³
}

\begin{abstract}
ABSTRAK
Penggunaan media KIT merupakan media yang bertujuan mengambangkan prestasi belajar peserta didik dengan menggunakan sebuah alat yang bisa memudahkan anak memahami pembelajaran. Prestasi belajar peserta didik kelas VI SDN Tirtalaya cenderung menurun. Rumusan masalah dari penelitian ini yaitu bagaimana pengaruh penggunaan media KIT terhadap prestasi belajar peserta didik pada Mata Pelajaran Ilmu Pengetahuan Alam di kelas VI SDN Tirtalaya. Tujuannya untuk mengetahui bagaimana pengaruh penggunaan media KIT terhadap prestasi belajar peserta didik pada Mata Pelajaran Ilmu Pengetahuan Alam di kelas VI SDN Tirtalaya.

Penelitian menggunakan metode deskriptif pendekatan kuantitatif. Populasi penelitian sebanyak 118 responden dengan sampel sebanyak 30 responden, pengambilan sampel menggunakan teknik Purposive Sampling. Teknik pengumpulan data menggunakan angket dan pedoman observasi. Pengolahan data kuantitatif diselesaikan melalui pengolahan data deskriptif dengan korelasi rank Spearman rs.

Berdasarkan hasil pengolahan data penggunaan media KIT pada mata pelajaran Ilmu Pengetahuan Alam mendapat nilai rata - rata hitung $(\overline{\mathrm{X}})$ sebesar 42, berada pada interval 41 - 44, penggunaan media KIT pada mata pelajaran Ilmu Pengetahuan Alam di kelas VI SDN Tirtalaya adalah baik. Prestasi belajar peserta didik kelas VI SDN Tirtalaya mendapat nilai rata - rata hitung (x) 79 berada pada interval 78 - 81 Maka prestasi belajar peserta didik kelas VI SDN Tirtalaya adalah rendah. Pengaruh Penggunaan Media KIT terhadap Prestasi Belajar Peserta Didik pada Mata Pelajaran Ilmu Pengetahuan Alam kelas VI SDN Tirtalaya mempunyai pengaruh yang positif serta signifikan dengan klasifikasi cukup, dibuktikan dengan nilai rs sebesar 0,49 berada pada interval 0,41 - 0,60, serta hasil dari perhitungan thitung dan ttabel mendapat hasil 2,974 $\geq 2,048$ maka Ha diterima $\mathrm{H} 0$ ditolak.

Disarankan bagi guru untuk mampu melaksanakan pembelajaran dengan maksimal, memotivasi dan memberi semangat kepada peserta didik hingga minat belajar mampu meningkat, serta untuk peserta didik disarankan agar senantiasa duduk di kursi terdepan.

Kata Kunci: media KIT; peserta didik; prestasi belajar.
\end{abstract}

\section{The effect of using media kits on student learning achievement}

(Research at SDN Tirtalaya Kec. Pagerageung Kab. Tasikmalaya) 


\section{ABSTRACT}

The use of KIT media is media that aims to develop students' learning achievement by using a tool that can make it easier for children to understand learning. Student achievement in grade VI SDN Tirtalaya tends to decrease.

The formulation of the problem of this research is how the influence of the use of KIT media on student achievement in Natural Sciences Subjects in class VI SDN Tirtalaya. The aim is to find out how the influence of the use of KIT media on students' learning achievements in Natural Sciences Subjects in class VI SDN Tirtalaya.

The research uses a descriptive quantitative approach method. The study population was 118 respondents with a sample of 30 respondents, sampling using the purposive sampling technique. Data collection techniques using questionnaires and observation guidelines. Quantitative data processing is completed through descriptive data processing with Spearman rank correlation rs.

Based on the results of data processing the use of KIT media on Natural Sciences subjects got an average count (x) of 42, at an interval of 41-44, the use of KIT media on Natural Sciences subjects in class VI SDN Tirtalaya is good. Student achievement in grade VI SDN Tirtalay got an average score $(x) 79$ at an interval of 78-81 So the learning achievement of grade VI SDN Tirtalaya is low. The Influence of the Use of KIT Media on Student Learning Acbievement in Natural Sciences Class VI SDN Tirtalaya has a positive and significant effect with sufficient classification, as evidenced by the rs value of 0.49 at intervals of $0.41-0.60$, and the results from the calculation of count and table obtained a result of 2.974 then $2.048 \mathrm{Ha}$ accepted $\mathrm{HO}$ was rejected.

Based on the results of this study, it is recommended for teachers to be able to carry out learning to the maximum, motivate and encourage students to interest in learning to increase, and students are advised to always sit in the front seat.

Keywords: KIT media; students; learning achievement.

\section{PENDAHULUAN}

Tujuan pendidikan yaitu berkembangnya potensi peserta didik menjadi manusia yang beriman dan bertakwa kepada tuhan yang Maha Esa, berakhlak mulia, sehat, berilmu cakap, kreatif, mandiri, dan menjadi warga negara yang demokratis serta bertanggung jawab. Peran seorang pendidik dalam membantu siswa mengoptimalkan dan mengaktualisasikan potensinya sangat tinggi. Pendidik bertugas mengemas proses pembelajaran termasuk dalam hal ini menciptakan kondisi belajar yang kondusif, menyenangkan dan membangkitkan motivasi. (Pasal 3 UU No 20 Sisdiknas Tahun 2003).

Syaiful Sagala (2009:61) mengatakan bahwa Pembelajaran adalah membelajarkan peserta didik menggunakan asas pendidikan maupun teori belajar yang merupakan penentu utama keberhasilan pendidikan". Tujuan pendidikan pada dasamya menghantarkan para peserta didik menuju pada perubahan tingkah laku, baik intelektual, moral maupun sosial peserta didik agar dapat hidup mandiri sebagai individu dan makhluk sosial. Proses pembelajaran pada hakikatnya adalah proses komunikasi, yaitu proses penyampaian pesan dari sumber pesan.

Sudjana (2009:92) mengatakan bahwa Ilmu Pengetahuan alam atau (sains) merupakan hasil kegiatan manusia berupa pengetahuan, gagasan dan konsep yang terorganisir secara logis dan sistematis tentang alam sekitar, yang diperoleh dari pengalaman melalui serangkaian proses ilmiah 
seperti: pengamatan, penyelidikan, penyusunan hipotesis yang diikuti dengan pengajuan gagasan. IPA berhubungan dengan cara mencari tahu tentang alam secara sistematis, sehingga IPA bukan hanya penguasaan kumpulan sistematis dan IPA bukan hanya penguasaan kumpulan pengetahuan yang berupa fakta-fakta, konsep-konsep atau prinsip-prinsip saja, tetapi juga merupakan suatu proses penemuan (Sri Sulistyorini, 2007: 39). Hakikat Pembelajaran IPA merupakan persiapan di masa depan, dalam hal ini masa depan kehidupan anak yang ditentukan orang tua. Oleh karenanya, sekolah mempersiapkan mereka untuk hidup dalam masyarakat yang akan datang. Pembelajaran merupakan suatu proses penyampaian pengetahuan, yang dilaksanakan dengan menuangkan pengetahuan kepada siswa (Oemar Hamalik, (2008: 25)). Sedangkan Ruang lingkup mata pelajaran IPA di Tingkat SD berdasarkan keputusan dari Mendikbud (2014: 232) yakni mencakup materi mata pelajaran IPA SD mencakup Tubuh dan panca indra, Tumbuhan dan hewan, Sifat dan wujud benda- benda sekitar, Alam semesta dan kenampakannya, Bentuk luar tubuh hewan dan tumbuhan, Daur hidup makhluk hidup, Perkembangbiakan tanaman, Wujud benda, Gaya dan gerak, Bentuk dan sumber energi dan energi alternatif, Rupa bumi dan perubahannya, Lingkungan, alam semesta, dan sumber daya alam, Iklim dan cuaca, Rangka dan organ tubuh manusia dan hewan, Makanan, rantai makanan, dan keseimbangan ekosistem, Perkembangbiakan makhluk hidup, Penyesuaian diri makhluk hidup pada lingkungan, Kesehatan dan sistem pernafasan manusia, Perubahan dan sifat benda, Hantaran panas, listrik dan magnet, Tata surya, Campuran dan larutan.

Untuk mencapai keberhasilan dalam pembelajaran IPA guru terus berusaha menyusun dan menetapkan strategi pembelajaran yang paliang efektif dan efisien untuk membantu peserta didik dalam mencapai tujuan yang telah dirumuskan, Salah satu strategi pembelajaran adalah metode yang menarik dengan penyajian bermacam-macam metode. Selain itu juga guru dituntut memiliki

Pengetahuan yang luas tentang media pembelajaran dan memiliki keterampilan untuk menerapkannya sehingga akan mengurangi kejenuhan dan kebosanan dalam proses pembelajaran karena sebagian siswa menganggap pelajaran IPA adalah pelajaran yang kurang menarik dibandingkan dengan pelajaran yang lainnya.

Rusman Faoz (2015:13) mengatakan bahwa Media pembelajaran adalah sebuah alat yang berfungsi untuk menyampaikan pesan pembelajaran. Media pembelajaran merupakan salah satu komponen pelajaran yang mempunyai peranan penting dalam kegiatan belajar mengajar. Penggunaan media pembelajaran pada tahap orientasi pembelajaran akan membantu keefektifan proses pembelajaran dalam penyampaian pesan dan isi pelajaran pada saat itu. Selain membangkitkan motivasi dan minat siswa, media pembelajaran juga dapat membantu siswa meningkatkan pemahaman, menyajikan data dengan menarik dan memadatkan informasi. 
Kemajuan ilmu dan teknologi, khususnya teknologi informasi, sangat berpengaruh terhadap penyusunan dan implementasi strategi pembelajaran. Melalui kemajuan tersebut guru dapat menggunakan berbagai media sesuai dengan kebutuhan dan tujuan pembelajaran. Dengan menggunakan media komunikasi bukan saja dapat mempermudah dan mengefektifkan proses pembelajaran, akan tetapi juga bisa membuat proses pembelajaran lebih menarik.

Peningkatan kualitas pendidikan disekolah dasarterdapat banyak faktor penentu keberhasilannya, salah satunyna adalah penggunaan KIT sebagai salah satu upaya meningkatkan kualitas pembelajaran, khususnya pada pembelajaran Ilmu Pengetahuan Alam. Pelaksanaan pembelajaran yang didukung dengan penggunaan KIT sebagai salah satu alat peraga pembelajaran yang tepat akan memberikan ransangan yang dapat memberikan motivasi untuk peserta didik. Artinya fungsi alat peraga yang digunakan oleh guru akan menarik kemauan siswa untuk sungguh-sungguh mengikuti pembelajaran.

Untuk menyatakan bahwa suatu proses belajar mengajar dapat dikatakan berhasil, setiap guru memiliki pandangan masing-masing sejalan dengan filosofinya. Namun, keberhasilan belajar dapat dilihat pada keberhasilan guru dalam mencapai tujuan pembelajaran itu sendiri. Keberhasilan belajar (prestasi belajar) peserta didik dapat dilihat dari ranah kognitif yaitu mengenal, pemahaman, penerapan, analisis, sintesis, evaluasi. Dengan demikian hasil belajar peserta didik dapat diukur melalui ranah koignitif yang artinya keberhasilan belajar peserta didik dilihat dari segi perubahanperubahan terhadap kemampuan peserta didik.

Berdasarkan observasi yang telah dilakukan di SDN Tirtalaya Kecamatan Pagerageung Kabupaten Tasikmalaya diperoleh informasi bahwa seringkali ditemukan hambatan-hambatan dalam proses pembelajaran Ilmu Pengetahuan Alam khususnya dalam penggunaan media KIT, peserta didik yang kurang dalam memahami materi yang disampaikan oleh guru melalui penggunaan KIT, peserta didik sering kesulitan menjawab evaluasi pelajaran. Penggunaan media KIT di SDN Tirtalaya sudah digunakan tapi hanya beberapa media KIT yang sering digunakan yakni Media KIT Ilmu pengetahuan Alam, maka dari itu di fokuskan penelitian terhadap media KIT Ilmu Pengetahuan Alam.

Dengan memperhatikan latar belakang diatas, maka penulis merasa tertarik untuk menjadikan permasalahan ini menjadi judul penelitian dengan judul "Pengaruh Penggunaan Media KIT Terhadap Prestasi Belajar Peserta Didik Pada Mata Pelajaran Ilmu Pengetahuan Alam" (Penelitian di SDN Tirtalaya Kec. Pagerageung Kab. Tasikmalaya).

Adapun rumusan masalah dalam penelitian ini adalah (1) Bagaimana penggunaan media KIT dalam mata pelajaran Ilmu Pengetahuan Alam di SDN Tirtalaya Kecamatan Pagerageung Kabupaten Tasikmalaya?, (2) Bagaimana prestasi belajar peserta didik pada mata pelajaran Ilmu 
Pengetahuan Alam di SDN Tirtalaya Kecamatan Pagerageung Kabupaten Tasikmalaya?, (3) Bagaimana pengaruh penggunaan media KIT terhadap prestasi belajar peserta didik dalam mata pelajaran Ilmu Pengetahuan Alam di SDN Tirtalaya Kecamatan Pagerageung Kabupaten Tasikmalaya?.

Adapun tujuan penelitian ini adalah (1) Untuk mengetahui penggunaan media KIT dalam mata pelajaran Ilmu Pengetahuan Alam di SDN Tirtalaya Kecamatan Pagerageung Kabupaten Tasikmalaya, (2) Untuk mengetahui prestasi belajar peserta didik pada mata pelajaran Ilmu Pengetahuan Alam di SDN Tirtalaya Kecamatan Pagerageung Kabupaten Tasikmalaya, (3) Untuk mengetahui pengaruh penggunaan media KIT dalam mata pelajaran Ilmu Pengetahuan Alam di SDN Tirtalaya Kecamatan Pagerageung Kabupaten Tasikmalaya.

Pendidikan merupakan usaha sadar yang dilakukan untuk mengemhangkan potensi yang dimiliki oleh setiap individu dengan berbagai upaya demi penyiapan dirinya di masa yang akan datang. Potensi yang dikembangkan meliputi kenampuan kognitif, afektif dan psikomotorik.

Peran pendidik dalam membantu siswa mengoptimalkan mengaktualisasikan potensinya sangat tinggi. Pendidik bertugas mengemas proses pembelajaran termasuk dalam hal ini menciptakan kondisi belajar yang kondusif. menyenangkan dan membangkitkan motivasi. Dalam mata pembelajaran Bahasa Indonesia misalnya, karena IPA bukan ilmu pasti seperti matematika. maka pendidik yang cenderung menggunakan metode ceramah atau hafalan menjadikan siswa cenderung bosan.

Kebosanan ini menimbulkan rendahnya minat dan motivasi siswa untuk berpartisipasi dalam proses pembelajaran (aktivitas belajar), jika hal ini terus menerus terjadi maka bukan tidak mungkin prestasi siswa akan rendah, dan tujuan pembelajaran yang tertuang dalam standar kompetensi lulusan tidak dapat terpenuhi. Aktivitas belajar itu sendiri digolongkan kedalam 8 kelompok diantaranya visual activities, oral activities, listening activities, writing activities, darwing activities, motor activities, mental activities, dan emotional activities.

Media pembelajaran merupakan alat bantu dalam proses belajar mengajar yang diperlukan oleh guru untuk membantu tugas guru dalam menyampaikan materi pelajaran. Pembelajaran tanpa bantuan media maka bahan pelajaran sukar untuk dicema dan dipahami oleh peserta didik terutama hahan pelajaran yang rumit. Tujuan media adalah untuk meningkatkan minat serta motivasi agar peserta didik ikut berpartisipasi dalam proses pembelajaran.

Kecanggihan teknologi saat ini memungkinkan untuk berekspresi maupun menyajikan informasi tidak hanya dalam bentuk gambar. Gambar yang bergerak sekaligus disertai musik dan suara. Media pendidikan memiliki peranan penting di dalam proses pembelajaran. Media pendidikan menuntut penggunaan media pendidikan dari yang sederhana sampai yang canggih. 
Media pembelajaran bukan hanya sekedar alat bantu, melainkan sebagai komponen yang sangat penting dalam pembelajaran.

Pemanfaatan media pembelajaran yang relevan dalam kelas dapat mengoptimalkan proses pembelajaran, media juga sangat membantu guru untuk mengkonkretkan konsep atau gagasan dan mampu menumbuhkan motivasi peserta didik belajar dengan aktif. Media juga menjadi jembatan untuk berfikir kritis bagi peserta didik. Melalui media juga peserta didik dapat lebih mengembangkan potensi kecerdasan, keterampilan motorik,kemampuan sosial, emosi dan kepribadian peserta didik.

Pembelajaran merupakan upaya membina sikap dan kleterampilan peserta didik melalui interaksi dengan lingkungan belajar. Tujuan dari sebuah pembelajaran dapat tercapai apabila proses belajar berlangsung secara efektif. Suatu pembelajaran dapat dikatakan efektif apabila peserta didik didorong untuk beraktifitas mempelajari materi pelajaran sesuai dengan topik-topik yang akan dipelajarinya.

Banyak media yang dapat digunakan dalam penyampaian sebuah materi kepada peserta didik, tetapi melihat fenomena dari pembelajaran Ilmu Pengetahuan Alam yang terjadi, maka diperlukan sebuah media yang dapat menunjang proses belajar pembelajaran Ilmu Pengetahuan Alam tersebut yakni dengan penggunaan media alat peraga KIT. Media KIT merupakan segala sesuatu yang digunakan untuk menjelaskan konsep pembelajaran dari dang bersifat abstak menjadi nyata sehingga dapat memberi stimulus kepada pikiran peserta didik untuk belajar.

Penggunaan media KIT juga sangat dianjurkan karena dengan penggunaan media KIT akan memudahkan sesuatu materi yang rumit ataupun sukar dipelajari akan menjadi lebih mudah untuk dipahami dan pembelajaran Ilmu Pengetahuan Alam akan lebih efektif, materi yang disampaikan pun bisa langsung diperagakan dan langsung melakukan percobaan.

Penggunaan media KIT merupakan komponen yang sangat penting. Dan keberhasilan pelaksanaan pendidikan salah satunya tergantung pada sebuah media pembelajaran

\section{METODE PENELITIAN}

Metode yang digunakan dalam penelitian ini adalah metode deskriptif dengan pendekatan kuantitatif. Menurut Wawan (2017:5) "Metode Deskriptif adalah metode penelitian yang berupaya untuk mengungkapkan keadaan/kondisi yang terjadi saat sekarang dengan mempertimbangkan keadaan masa lampau".

Dengan metode deskriptif memungkinkan untuk melakukan hubungan menguji hipotesis. antar variabel, mengembangkan generalisasi, dan mengembangkan teori yang memiliki validitas 
universal. Sedangkan pendekatan kuantitatif adalah yang bersifat korelasi, semua data yang diperoleh diwujudkan dalam bentuk angka, skor dan analisisnya menggunakan statistik.

Melalui metode ini diharapkan dapat memperoleh gambaran secara sistematis. faktual dan akurat mengenai fakta-fakta serta pengaruh terhadap fenomena yang diteliti, yakni tentang pengaruh penggunaan media KIT terhadap prestasi belajar peserta didik pada mata pelajaran Ilmu Pengetahuan Alam.

Sugiyono (2017:38) mengatakan "variabel penelitian pada dasarnya adalah segala sesuatu yang berbentuk apa saja yang ditetapkan oleh peneliti untuk dipelejari sehingga diperoleh informasi tentang hal tersebut, kemudian ditarik kesimpulannya".Dalam penelitian ini ada 2 variabel, variabel indevenden $(\mathrm{X})$ adalah media KIT sedangkan variabel dependen $(\mathrm{Y})$ adalah prestasi belajar.

Populasi penelitian ini adalah seluruh siswa SDN Tirtalaya, Jalan Cikoranji, Desa Tanjungkerta, Kecamatan Pagerageung, Kabupaten Tasikmalaya yang berjumlah 118 siswa. Teknik yang digunakan dalam penelitian adalah teknik purposive sampling. yang dijadikan sampel adalah kelas VI, hal ini dikarenakan kelas VI adalah kelas yang memiliki kelengkapan KIT Ilmu Pengetahuan Alam yang lengkap, prestasi belajar yang baik serta karakteristik peserta didik yang sesuai dengan keinginan peneliti

Instrumen penelitian yang digunakan pada penelitian ini yaitu angket atau Kuisioner. Angket merupakan teknik pengumpulan data utama berupa sejumlah pertanyaan/pernyataan tertulis yang digunkan untuk menggali data pokok dari responden (peserta didik) untuk memperoleh informasi atau hal hal yang diketahui, mengenai pengaruh penggunaan media KIT terhadap Prestasi belajar peserta didik dalam mata pelajaran Ilmu pengetahuan Alam. Angket disusun untuk mengetahui data tentang keadaan pelaksanaan penggunaan KIT yang digunakan oleh guru pada proses pembelajaran Ilmu Pengetahuan Alam.

Bentuk angket yang digunakan adalah berupa pertanyaan pilihan ganda (multiple choise) dengan banyak alternatif jawaban 4 option. Setiap option memiliki skor nominal yang ditentukan oleh sifat pertanyaan/pernyataan yang tersusun. Untuk option (a) memiliki skor 4, (b) 3, (c) 2, (d) 1. Banyaknya pertanyaan dalam angket adalah 15 pertanyaan. dimana 15 pertanyaan mengenai pengaruh penggunaan KIT sebagai variabel bebas $(X)$.

Pengolahan dan analisis data yang benar harus bertitik tolak dari rumusan masalah atau sub variabel yang ingin dicari jawabannya melalui penelitian. Maka dalam analisis data ini adalah mencari pengaruh antara variabel $(\mathrm{X})$ terhadap variabel $(\mathrm{Y})$ menggunakan analisis Rank Spearman (rs). 
Metode yang digunakan dalam penelitian ini adalah metode deskriptif dengan pendekatan kuantitatif. Dengan metode deskriptif memungkinkan untuk melakukan hubungan menguji hipotesis. antar variabel, mengembangkan generalisasi, dan mengembangkan teori yang memiliki validitas universal. Sedangkan pendekatan kuantitatif adalah yang bersifat korelasi, semua data yang diperoleh diwujudkan dalam bentuk angka, skor dan analisisnya menggunakan statistik.

Melalui metode ini diharapkan dapat memperoleh gambaran secara sistematis. faktual dan akurat mengenai fakta-fakta serta pengaruh terhadap fenomena yang diteliti, yakni tentang pengaruh penggunaan media KIT terhadap prestasi belajar peserta didik pada mata pelajaran Ilmu Pengetahuan Alam.

Populasi penelitian ini adalah seluruh siswa SDN Tirtalaya tahun ajaran 2019/2020, Jalan Cikoranji, Desa Tanjungkerta, Kecamatan Pagerageung, Kabupaten Tasikmalaya yang berjumlah 118 siswa.

Teknik yang digunakan dalam penelitian adalah teknik purposive sampling. yang dijadikan sampel adalah kelas VI, hal ini dikarenakan kelas VI adalah kelas yang memiliki kelengkapan KIT Ilmu Pengetahuan Alam yang lengkap, prestasi belajar yang baik serta karakteristik peserta didik yang sesuai dengan keinginan peneliti

Instrumen penelitian yang digunakan pada penelitian ini yaitu angket atau Kuisioner. Angket merupakan teknik pengumpulan data utama berupa sejumlah pertanyaan/pernyataan tertulis yang digunkan untuk menggali data pokok dari responden (peserta didik) untuk memperoleh informasi atau hal hal yang diketahui, mengenai pengaruh penggunaan media KIT terhadap Prestasi belajar peserta didik dalam mata pelajaran Ilmu pengetahuan Alam. Angket disusun untuk mengetahui data tentang keadaan pelaksanaan penggunaan KIT yang digunakan oleh guru pada proses pembelajaran Ilmu Pengetahuan Alam.

Bentuk angket yang digunakan adalah berupa pertanyaan pilihan ganda (multiple choise) dengan banyak alternatif jawaban 4 option. Setiap option memiliki skor nominal yang ditentukan oleh sifat pertanyaan/pernyataan yang tersusun. Untuk option (a) memiliki skor 4, (b) 3, (c) 2, (d) 1. Banyaknya pertanyaan dalam angket adalah 15 pertanyaan. dimana 15 pertanyaan mengenai pengaruh penggunaan KIT sebagai variabel bebas (X).

Pengolahan dan analisis data yang benar harus bertitik tolak dari rumusan masalah atau sub variabel yang ingin dicari jawabannya melalui penelitian. Maka dalam analisis data ini adalah mencari pengaruh antara variabel $(\mathrm{X})$ terhadap variabel $(\mathrm{Y})$ menggunakan analisis Rank Spearman (rs). 
Metode penelitian pada naskah artikel menjelaskan jenis penelitian, subjek dan objek penelitian, waktu dan lokasi penelitian, instrumen penelitian, cara pengambilan sampel, pengumpulan data, dan analisis data.

\section{HASIL DAN PEMBAHASAN}

Berdasarkan hasil uji statistik diperoleh rata - rata hitung ( $\mathrm{X}) 42$ bila dikonfirmasi pada skala penafsiran berada pada klasifikasi 41 - 44. Maka dapat disimpulkan bahwa penggunaan media KIT pada mata pelajaran Ilmu Pengetahuan Alam di kelas VI SDN Tirtalaya adalah baik. Hal ini menunjukan bahwa penggunaan media KIT pada mata pelajaran Ilmu Pengetahuan Alam di kelas VI SDN Tirtalaya sudah dilaksanakan dengan baik.

Sebagaimana hasil uji statistik yang menyatakan bahwa penggunaan media KIT pada mata pelajaran Ilmu Pengetahuan Alam di kelas VI SDN Tirtalaya tergolong baik, begitupun dengan hasil observasi di kelas VI SDN Tirtalaya, yang menyatakan bahwa penggunaan media KIT pada mata pelajaran Ilmu Pengetahuan Alam di kelas VI SDN Tirtalaya sudah diterapkan dengan baik malai dari perencanaan, pelaksanaaan, metode Penyampaian, bahan ajar dan tujuan akhir.

Peserta didik mampu menyiapkan media KIT dengan bahan bahan alami sendiri, selalu mengamati percobaan yang di lakukan guru, dsn mampu menyimpulkan apa yang telah dipelajari. Peserta didik belajar dengan pengamatan melalui panca indera yang banyak memerlukan penggunaaan alat peraga. Penggunaan alat peraga sebagai alat bantu agar memudahkan peserta didik dalam menghapal pengertian-pengertian yang diinginkan, salah satu kegunaan KIT Ilmu Pengetahuan Alam adalah untuk meningkatkan mutu pengajaran dan peningkatan pembelajaran Ilmu Pengetahuan Alam

Berdasarkan hasil uji statistik diperoleh rata - rata hitung $(\overline{\mathrm{X}}) 79$ bila dikonfirmasi pada skala penafsiran berada pada klasifikasi 78 - 81 Maka dapat disimpulkan bahwa prestasi belajar peserta didik kelas VI SDN Tirtalaya adalah rendah. Hal ini menunjukan prestasi belajar peserta didik kelas VI SDN Tirtalaya belum sepenuhnya memenuhi kriteria atau indikator prestasi belajar peserta didik antara lain rasa ingin untuk belajar, selalu memperhatikan ketika belajar, aktif, selalu merasa senang sehingga mampu merubah tingkah laku peserta didik baik dalam aspek pengetahuan, sikap maupun keterampilan.

Sebagaimana uji statistik yang menyatakan bahwa prestasi belajar peserta didik kelas VI SDN Tirtalaya tergolong rendah, begitupun dengan hasil observasi penelitian di SDN Tirtalaya yang menyatakan bahwa prestasi belajar peserta didik kelas VI SDN Tirtalaya pada awalnya masih rendah, dan setelah adanya penggunaan media KIT pada mata pelajaran Ilmu Pengetahuan Alam prestasi belajar peserta didik kelas VI SDN Tirtalaya belum terlihat maksimal, sebagian peserta 
didik terlihat kurang maksimal dalam mengikuti pembelajaran Namun ada sebagian kecil peserta didik kelas VI SDN Tirtalaya yang terlihat antusias mengikuti pembelajaran menggunakan media KIT pada mata pelajaran Ilmu Pengetahuan Alam.

Sebagaimana dijelaskan Muhibbin Syah (2010:141) bahwa Prestasi adalah tingkat keberhasilan siswa dalam mencapai tujuan yang telah ditetapkan dalam sebuah program. Sedangkan Cucu Suhana (2014:5) mengatakan bahwa Belajar telah mengalami perkembangan secara evolusi, sejalan dengan perkembangan cara pandang dan pengalaman para ilmuan, dan Zainal Aqib (2014 : 66) mengemukakan bahwa Belajar menurut teori behavioristik diartikan sebagai proses perubahan tingkah laku. Perubahan tersebut disebabkan oleh seringnya interaksi antara stimulus dan respons.

Menurut teori kognitif belajar diartikan proses untuk membangun persepsi seseorang dari sebuah objek yang dilihat, oleh sebab itu belajar menurut teori ini lebih mementingkan proses dari pad hasil. Sedangkan belajar menurut teori konstruktivisme belajar adalah upaya untuk membangun pemahaman atau persepsi atas dasar pengalaman yang dimulai siswa, oleh sebab itu belajar menurut teori konstruktivisme merupakan proses untuk memberikan pengalaman nyata bagi siswa.

Dalam ranah kognitif peserta didik mampu mengingat teori - teori yang telah dipelajari, menjelaskan kembali dan menerapkan apa yang telah dipelajari di dalam kelas. Dalam ranah Afektif peserta didik mampu ikut berpartisipasi dalam diskusi kelas dan dalam ranah Psikomotorik Peserta didik sudah mulai berani untuk bertanya kepada guru pelajaran Ilmu pengetahuan Alam tentang dan dapat memberikan penjelasan kepada teman-teman sekelasnya di sekolah, atau kepada adikadiknya di rumah, atau kepada anggota masyarakat lainya, tentang planet yang dekat paling dekat dengan matahari sampai planet yang jauh dari matahari.

Berdasarkan hasil penelitian dapat diketahui bahwa penggunaan media KIT pada mata pelajaran Ilmu Pengetahuan Alam cukup berpengaruh terhadap prestasi belajar peserta didik kelas VI SDN Tirtalaya dengan harga rs sebesar 0,49. Berdasarkan klasifikasi guilford, maka nilai rs sebesar 0,49 berada pada klasifikasi cukup (Moderate), karena berada diantara 0,41 - 0,60. Hal ini berarti bahwa penggunaan media KIT pada mata pelajaran Ilmu Pengetahuan Alam mempunyai korelasi yang cukup dengan prestasi belajar peserta didik SDN Tirtalaya. Artinya indikator penggunaan media KIT pada mata pelajaran Ilmu Pengetahuan Alam cukup mempengaruhi indikator prestasi belajar peserta didik kelas VI SDN Tirtalaya, seperti melaksanakan pembelajaran dengan mengemasnya menjadi permainan dan kerjasama tim mampu meningkatkan keaktifan, rasa senang dan keinginan untuk belajar menjadi sedikit terbangun, sehingga perubahan tingkah laku baik dalam aspek pengetahuan, sikap ataupun keterampilan dapat terbangun meskipun tidak signifikan. 
Kontribusi atau derajat determinasi indikator penggunaan media KIT terhadap prestasi belajar peserta didik pada mata pelajaran Ilmu Pengetahuan Alam kelas VI SDN Tirtalaya sebesar $24 \%$. Hal ini berarti bahwa dengan penggunaan media pembelajaran mempengaruhi prestasi belajar peserta didik 24\% dan sisanya 76\% ditentukan oleh faktor lain seperti kesehatan, psikologis, kelelahan jasmani maupun rohani, tujuan pembelajaran, guru yang mengajar, bahan pelajaran dan lingkungan.

Selanjutnya untuk mengetahui apakah hubungan itu signifikan atau tidak maka dibandingkanlah thitung dengan ttabel. Maka diperoleh perbandingan antara thitung dengan ttabel $(2,974 \geq 2,048)$.dengan demikian hipotesis alternatif ( $\mathrm{Ha}$ ) diterima, artinya penggunaan media KIT pada mata pelajaran Ilmu Pengetahuan Alam memiliki pengaruh yang bernilai positif terhadap prestasi belajar peserta didik kelas VI SDN Tirtalaya.

Adapun masalah yang timbul dari adanya kesenjangan bahwa penggunaan media KIT pada mata pelajaran Ilmu Pengetahuan Alam hanya sedikit berpengaruh terhadap prestasi belajar peserta didik kelas VI SDN Tirtalaya. Hal ini karena adanya beberapa penyebab yang ditimbulkan yakni : Penggunaan media KIT belum direspon secara baik oleh peserta didik kelas VI SDN Tirtalaya, Kurangnya motivasi dari guru baik secara verbal maupun non verbal, hal ini tentunya dapat mempengaruhi peserta didik, Masih banyak peserta didik yang enggan untuk belajar, peserta didik terlihat tidak bersemangat pada saat bel tanda masuk kelas dibunyikan.

\section{SIMPULAN}

Berdasarkan hasil uji statistik diperoleh rata - rata hitung $(\overline{\mathrm{X}}) 42$ bila dikonfirmasi pada skala penafsiran berada pada klasifikasi 41 - 44. Maka dapat disimpulkan bahwa penggunaan media KIT pada mata pelajaran Ilmu Pengetahuan Alam di kelas VI SDN Tirtalaya adalah baik. Penggunaan media KIT pada mata pelajaran Ilmu Pengetahuan Alam di kelas VI SDN Tirtalaya tergolong baik. Prestasi belajar peserta didik kelas VI SDN Tirtalaya tergolong kriteria atau indikator prestasi belajar peserta didik yang diharapkan. Penggunaan media KIT pada mata pelajaran Ilmu Pengetahuan Alam di kelas VI SDN Tirtalaya cukup berpengaruh terhadap prestasi belajar peserta didik kelas VI SDN Tirtalaya.

\section{DAFTAR PUSTAKA}

Anjasari. 2013. Pengembangan Pembelajaran IPA Terpadu (Implementasi Kurikulum 2013). Yogyakarta : FMIPA

Aqib, Zainal. 2014. Model-Model Media Dan Strategi Pembelajaran Kontekstual (Inofatif). Bandung : Yrama Widya

Arifin. 2010. Evaluasi Pembelajaran. Bandung : Remaja Rosda Karya 
Depdiknas. 2003. Undang-Undang Republik Indonesia No 20 Tahun 2003 tentang Sistem Pendidikan Nasional. Jakarta : Departemen Pendidikan dan Kebudayaan Rtepublik Indonesia.

Djamarah dan Zain. 2010. Strategi Belajar Mengajar. Jakarta : PT Rineka Cipta

Faoz, Rusman. 2015. Media Pembelajaran Berbasis Sains. Tasikmalaya : Latifah Press

Hamalik, Oemar. 2008. Motivasi Belajar. Bandung : Rajawali pers

Majid, Abdul. 2011. Perencanaan Pembelajaran. Bandung : PT Remaja Rosda Karya

Nasution, S. 2012. Didaktik. Asas-Asas Mangajar. Jakarta : Bumi Aksara

Rusman. 2017. Belajar dan Pembelajaran Berorientasi Standar Proses Pendidikan. Jakarta : PT Remaja Rosda Karya

Sagala, Syaiful. 2009. Konsep dan makna Pembelajaran. Bandung: Alfabeta

Sri, Y.M. 2006. Konsep Dasar IPA. Bndung : UPI Press

Subana dkk. 2005. Statistik Pendidikan. Bandung : Pustaka Setia

Sudjana, Nana dan Ahmad Rivai. 2003. Media Pengajaran. Bandung : Sinar Baru Algensindo

Suhana, Cucu. 2014..Konsep Strategi Pembelajaran. Bandung : Refika aditama

Sugiyono. 2013. Metode Penelitian Kuantitatif, Kualitatif dan R\&D. Bandung : Alfabeta

Sutrisno. Kresnadi dan kartono. 2007. Pengembangan pembelajaran IPA SD. Jakarta : Dikjen Dikti

Suyitno. 2002. Hakikat Pembelajaran IPA di SD

Syah, Muhibbin. 2010. Psikologi Pendidikan. Bandung : Remaja RosdaKarya

Syah, Muhibbin. 2018. Psikologi Belajar. Jakarta : PT Raja Grafindo Rosada

Wasih Djojosoediro. 1999. Hakikat IPA dan Pembelajaran IPA SD. Yogyakarta: Pustaka Pelajar

Wawan. 2015. Desain Penelitian Kuantitatif. Tasikmalaya : CV Latifah

Wawan. 2015. Pengantar Statistika Pendidikan. Tasikmalaya : CV Latifah 